\title{
Antibacterial Activity of Different Extracts from Rumex crispusL. Roots
}

Hassan Faesal Al-Mola

Firas Abbas Al-Bayati

Dept. of Biology / College of Education / University of Mosul

Received

$30 / 7 / 2006$
Accepted

3/10/2006

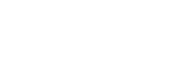

تضضمنت الدرلسة التأثير التثبيل لمستخلصت جذور نبلت الحميض في ثمانية أنواع من الجراثيم الموجبة وللسالبة لصبغة كرلم Bacillus cereus، Staphylococcus aureus ، Serratia marcescens، Proteus vulgaris ، Pseudomonas aeruginosa Klebsiella pneumoniae galmonella typhimurium ، Escherichia coli ومقارنتها مع المضادات الحيوية القيلسية. وقد لظهر المستخلص الايثانولي تأثيرا جيدا ن سبيا

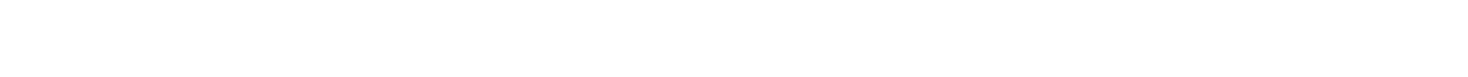

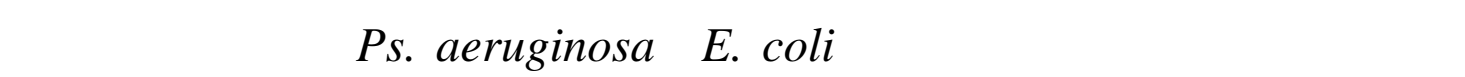
لوفظ أن الجراثيم Sal. typhimurium ، Serr. marcescens ، Kleb. Pneumoniae قاومت المستخلصت النباتية.

\section{Abstract}

In the present study, antibacterial properties of different extracts from Rumex crispus L. roots were screened against eight types of Grampositive and negative bacteria including Staphylococcus aureus, Bacillus cereus Pseudomonas aeruginosa, Proteus vulgaris, Serratia marcescens, Escherichia coli, Salmonella typhimurium, Klebsiella pneumoniae and compared with standard antibiotics. The ethanol extract demonstrated significant inhibitory effects against most bacteria under test compared with acetone and aqueous extract, which gave clear inhibitory effect against E. coli and Ps. aeruginosa, the study also revealed the resistance of Serr. marcescens, Sal. typhimurium and Kleb. pneumoniae against the different extracts used. 


\section{Introduction}

Traditional medicines based mostly on medicinal plants have been used for the treatment of various diseases by mankind for centuries. Plants are also well-known to be the rich sources of biologically active compounds. Due to increased resistance of many microorganisms toward established antibiotics, much recent attention has been paid to extracts and biologically active compounds isolated from plant species used in herbal medicine [1].

R. crispus L. (Yellow dock, Curled dock) subjected to Polygonaceae family first described by Carlos Linnaeus in 1753, is a small herb, leafy plant that grows wild in North Africa and Middle East [2]. The green leaves of R.crispus L. are commonly used in salads, while the yellow root has been used as a herbal folk-remedy for hundreds of years, its reported that it contains compounds such as anthracen glycosides $(0.2-1.7 \%)$, catechic tannin $(6-12 \%)$, resins and iron with no toxic substances $[3,4]$, yellow dock root makes a bitter-sweet tea that has been used to treat enlarged liver, purification of blood, diarrhea and stomach distress [5].

The genus Rumex includes other species like $R$. abyssinicus, $R$. nervosus, $R$. scutatus which are widely used in folk medicine as wound treatment, Eczema, Typhus and Rabies [6], in addition to there antibacterial activities against several bacteria including S. aureus and Ps. aeruginosa [7].

\section{Materials and methods}

\section{Microorganisms}

The microorganisms used included Escherichia coli, Staphylococcus aureus, Pseudomonas aeruginosa, Proteus vulgaris, Bacillus cereus, Serratia marcescens, Salmonella typhimurium and Klebsiella pneumoniae which were obtained from Department of Biology, College of Education, University of Mosul, then were diagnosed by using characteristics features.

\section{Plant material}

Roots of $R$. crispus L. were collected from Mosul countryside, Ninewa province in July 2006 and was identified at Department of Biology, College of Science / University of Mosul. 


\section{Preparation of Extracts}

Yellow dock roots were washed then dried at room temperature in dark then grinded to powder using an electrical blender.

\section{Aqueous and Ethanol extracts}

Aqueous extracts were prepared according to [8], which includes mixing 40gm of plant powder with $160 \mathrm{ml}$ of distilled water, after stirring, the extract was kept overnight in freezer then filtered using Whatman filter paper No.1, the filtrate were then evaporated using Edwards Lyophilizer. The dried extract was stored in sterile bottles at $20^{\circ} \mathrm{C}$ until use.

Ethanol extracts were carried out according to [9], which includes mixing 40gm of plant powder with $400 \mathrm{~mL}$ ethanol(concentration 95\%), after stirring the extract was kept overnight at room temperature, then filtered using Whatman filter paper No.1, and evaporated under reduced pressure using a rotary evaporator at $40^{\circ} \mathrm{C}$.The dried extract was stored in sterile bottles until further use.

\section{Hexane and Acetone extracts}

Plant material (Roots) were extracted using a soxhlet extractor with solvents of increasing polarity beginning with hexane followed by acetone, each extraction was carried out for 8-10 hours continuously .The solvent was removed using a rotary vacuum evaporator at $40^{\circ} \mathrm{C}$. Several concentrations of the extracts $\left(200,100,50,25\right.$ and $\left.12.5 \mathrm{mg} \mid \mathrm{cm}^{3}\right)$ were accomplished by dissolving in DMSO (Dimethylsulphaoxide), then were sterilized via pasturalization and kept under refrigerated conditions until use.

\section{Screening of antibacterial activity}

Antibacterial activity of the plant extracts was determined by disc diffusion method [10], Bacteria were cultured at $37^{\circ} \mathrm{C}$ for 24 hours in Nutrient broth (Oxoid). An inoculum containing $10^{8} \mathrm{cfu} / \mathrm{ml}$ (comparing with McFarland density $10^{8} \mathrm{cfu} / \mathrm{ml}$ ), was spread on Mueller-Hinton Agar (Oxoid) plates (1 ml incolum/plate). Filter paper discs (Whatman No.1 : $6 \mathrm{~mm}$ in diameter) were sterilized at $140^{\circ} \mathrm{C}$ for one hour and soaked with different concentrations of plant extracts by adding $0.1 \mathrm{~mL}$ of extract $/ 10$ paper disc, then placed on the surface of the inoculated media plates slightly. Petri dishes were left 1 hour for absorption before moving them for incubation at $37^{\circ} \mathrm{C}$ for 24 hours [11]. At the end of the period, inhibition zones formed on the medium were evaluated in $\mathrm{mm}$. 


\section{Results and Discussion}

The inhibitory effect of Yellow dock root extracts were compared with four types of antibiotics (Bioanalyse), (Amoxicillin $25 \mu \mathrm{g}$,

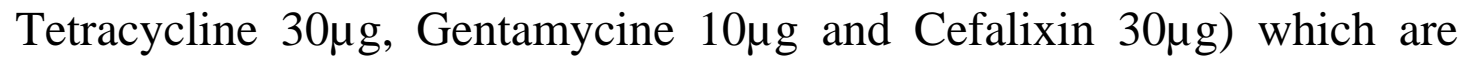
specified to inhibit the different bacteria used in this study.

As in (Table 1) the aqueous extract of yellow dock roots exhibited inhibitory action against $E$. coli with an inhibition zone of $27.2 \mathrm{~mm}$ in diameter, meanwhile a medium effect was observed against $P$ s. aeruginosa, the results obtained with this extract revealed no growth inhibition against the other test bacteria used in this study, which may refer that water is not the most effective solvent at extracting the active compounds from plants [12].

The ethanol extract from the same source showed only inactivity against Serr. marcescens, Sal. typhimurium, Kleb. pneumoniae. On the other hand, it was active against S. aureus, Ps. aeruginosa, Pr. vulgaris, E. coli, B. cereus with an inhibition zone between $14-16.5 \mathrm{~mm}$ (Figure $1 \mathrm{~A}, \mathrm{~B})$, these differences may be attributed to the cell wall complexion, muco polysaccharide extracellular substances, and capsule secretion by Kleb. pneumoniae which are the general factors in bacterial defense against antibiotics [13,14], in addition to the chemical complexion of bacterial cell wall and the number of its layers which also achieves resistance against antibiotics, and the role of cell wall pores in substance insertion inside bacterial cells, and ability of bacteria in changing the diameter of these pores so it can prevent large amount of substance insertion [15]. 
Table 1: Antibacterial activity of Aqueous and Ethanol extracts from $R$. crispusL. roots.

\begin{tabular}{|c|c|c|c|c|c|c|c|c|c|c|c|c|c|c|}
\hline \multirow{2}{*}{ Microorganisms } & \multicolumn{5}{|c|}{$\begin{array}{c}\text { Aqueous extract } \\
\text { concentrations } \mathrm{mg} / \mathrm{cm}^{3}\end{array}$} & \multicolumn{5}{|c|}{$\begin{array}{c}\text { Ethanol extract } \\
\text { concentrations } \mathrm{mg} / \mathrm{cm}^{3}\end{array}$} & \multicolumn{4}{|c|}{ Control } \\
\hline & 200 & 100 & 50 & 25 & 12.5 & 200 & 100 & 50 & 25 & 12.5 & TE & $\mathbf{A X}$ & $\mathbf{C N}$ & $\mathbf{C L}$ \\
\hline S. aureus & $\mathrm{R}$ & $\mathrm{R}$ & $\mathrm{R}$ & $\mathrm{R}$ & $\mathrm{R}$ & 15.5 & 12.2 & 11.2 & 9.4 & 7.6 & - & $\mathrm{R}$ & - & - \\
\hline Ps. aeruginosa & 12.3 & 10.2 & 8.5 & $\mathrm{R}$ & $\mathrm{R}$ & 16.8 & 14.5 & 10.6 & 8.4 & $\mathrm{R}$ & - & - & 19.1 & - \\
\hline Pr. vulgaris & $\mathrm{R}$ & $\mathrm{R}$ & $\mathrm{R}$ & $\mathrm{R}$ & $\mathrm{R}$ & 14.7 & 10.4 & 9.3 & 7.5 & $\mathrm{R}$ & $\mathrm{R}$ & - & - & - \\
\hline Ser. marcescens & $\mathrm{R}$ & $\mathrm{R}$ & $\mathrm{R}$ & $\mathrm{R}$ & $\mathrm{R}$ & $\mathrm{R}$ & $\mathrm{R}$ & $\mathrm{R}$ & $\mathrm{R}$ & $\mathrm{R}$ & - & - & 19.2 & - \\
\hline E. coli & 27.2 & 23.5 & 13.7 & 9.2 & $\mathrm{R}$ & 16.8 & 14.5 & 12.7 & 8.2 & $\mathrm{R}$ & - & - & 13.4 & - \\
\hline B. cereus & $\mathrm{R}$ & $\mathrm{R}$ & $\mathrm{R}$ & $\mathrm{R}$ & $\mathrm{R}$ & 15.6 & 11.5 & 10.6 & 7.2 & $\mathrm{R}$ & - & - & - & 12.1 \\
\hline Sal. typhimurium & $\mathrm{R}$ & $\mathrm{R}$ & $\mathrm{R}$ & $\mathrm{R}$ & $\mathrm{R}$ & $\mathrm{R}$ & $\mathrm{R}$ & $\mathrm{R}$ & $\mathrm{R}$ & $\mathrm{R}$ & - & - & $\mathrm{R}$ & - \\
\hline Kleb. pneumoniae & $\mathrm{R}$ & $\mathrm{R}$ & $\mathrm{R}$ & $\mathrm{R}$ & $\mathrm{R}$ & $\mathrm{R}$ & $\mathrm{R}$ & $\mathrm{R}$ & $\mathrm{R}$ & $\mathrm{R}$ & - & - & - & 16.2 \\
\hline
\end{tabular}

R: Resistant, - : Not used, TE: Tetracycline, AX: Amoxicillin, CN: Gentamycin, CL: Cefalixin 


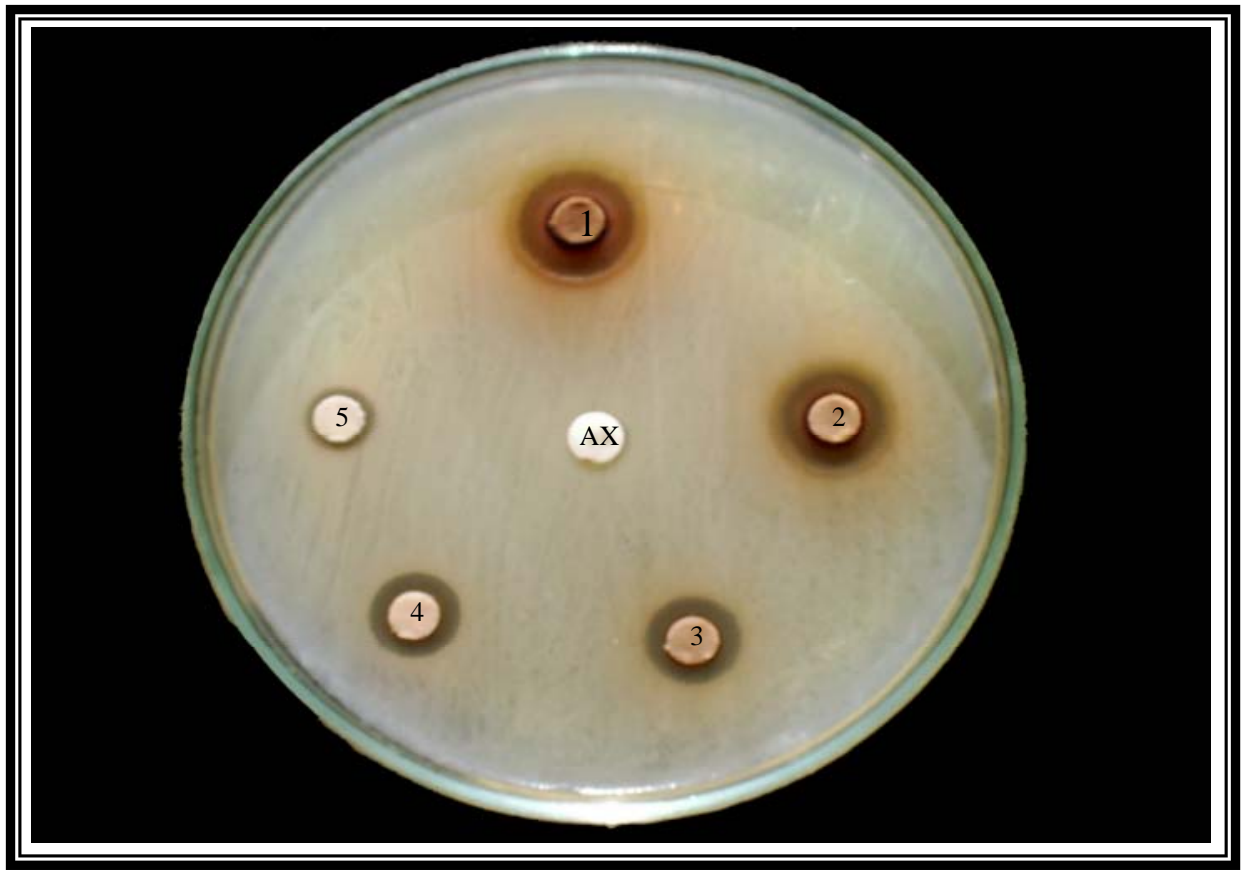

Figure 1(A):Effect of Ethanol extract on Staph. aureus using different concentration, $1\left(200 \mathrm{mg} / \mathrm{cm}^{3}\right) 2\left(100 \mathrm{mg} / \mathrm{cm}^{3}\right)$ $3\left(50 \mathrm{mg} / \mathrm{cm}^{3}\right) 4\left(25 \mathrm{mg} / \mathrm{cm}^{3}\right) 5\left(12.5 \mathrm{mg} / \mathrm{cm}^{3}\right)$ AX(Amoxicillin).

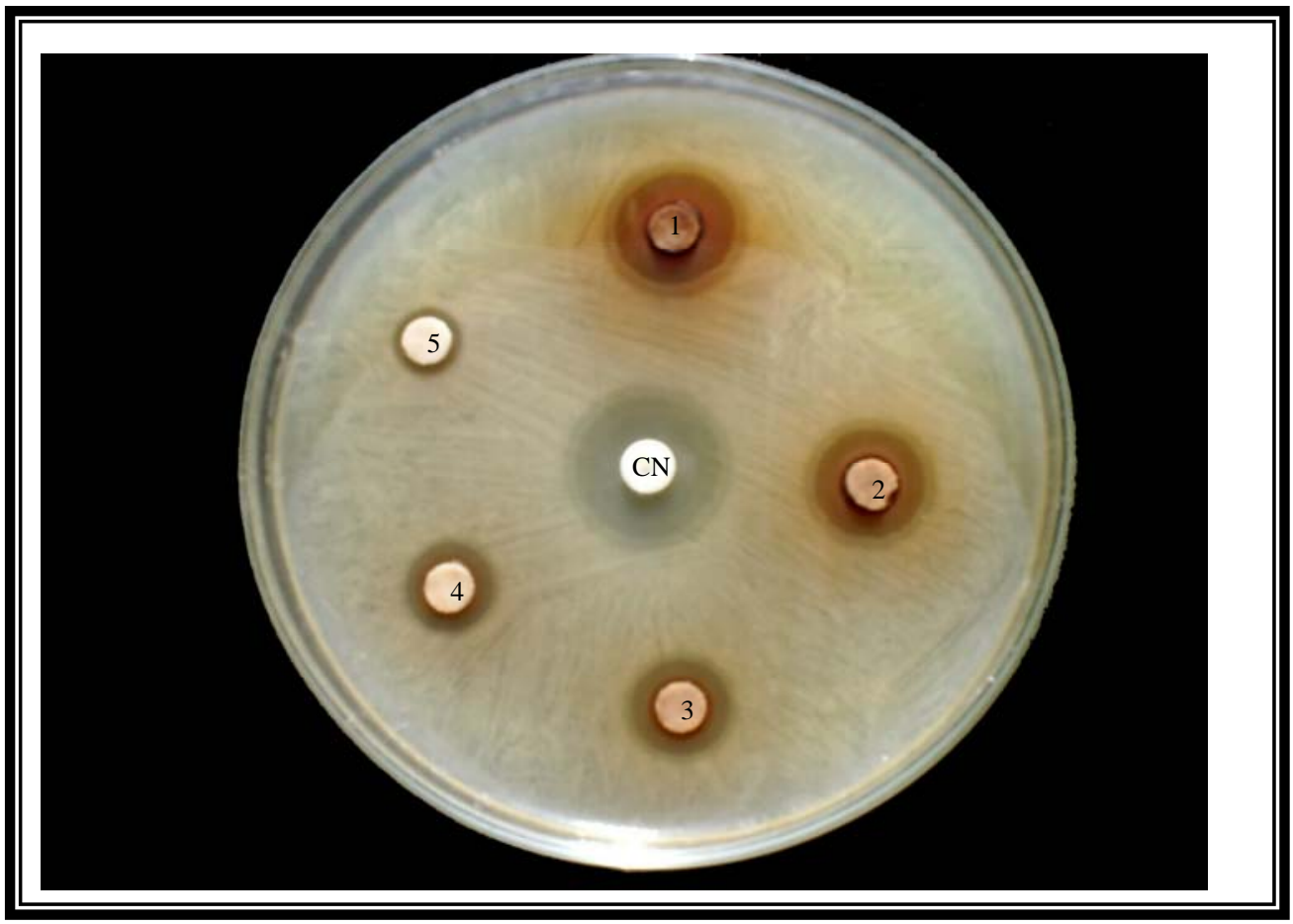

Figure 1(B):Effect of Ethanol extract on Ps .aeruginosa using different concentration , $1\left(200 \mathrm{mg} / \mathrm{cm}^{3}\right) 2\left(100 \mathrm{mg} / \mathrm{cm}^{3}\right)$ $3\left(50 \mathrm{mg} / \mathrm{cm}^{3}\right) 4\left(25 \mathrm{mg} / \mathrm{cm}^{3}\right) 5\left(12.5 \mathrm{mg} / \mathrm{cm}^{3}\right) \mathrm{CN}($ Gentamycin$)$. 
The acetone extract of Yellow dock roots showed high inhibitory effects against S. aureus, Ps. aeruginosa, Pr. vulgaris, E. coli and B. cereus (Table 2), the effect was very clear against E. coli and Ps. aeruginosa which recorded an inhibition zone reached $21.3 \mathrm{~mm}$ and $19.6 \mathrm{~mm}$ (Figure 2A) in diameter respectively, the proportion between the effect and extract concentration was direct.

Due to high concentration of tannins in Yellow dock roots, the plant extract was able to kill and inhibit bacterial growth by changing the structure of transport proteins and forming polysaccharide complex of envelope [13], in addition to the presence of anthraquinones which are chemical compounds that show antibacterial, antifungal, antiviral and antioxidant activities [5], the acetone extract showed no inhibition against Serr. marcescens, Sal. typhimurium and Kleb. Pneumoniae, these bacterial species may be able to prevent extract molecules from approaching inside their cells by changing cell membrane permeability [16], this study also disagreed with [17] which reported the susceptibility of Kleb. pneumoniae against the acetone extract with inhibition zone $16 \mathrm{~mm}$ in diameter, which may be consequence of different types of strain, isolation area, and different assay methods.

The hexane extract of Yellow dock roots also included inhibition effects against Ps. aeruginosa, the calculated zone was $21.3 \mathrm{~mm}$ in diameter (Figure 2B), meanwhile a moderate susceptibility was shown by $S$. aureus against the same extract (Table 2), the proportion was also direct between the effect and extract concentration. No inhibition zone was detected against the other types of bacteria, the difference in the results may refer to the inability of the hexane solvent to dissolve active components, in reversal of acetone and ethanol solvents, or the concentration $200 \mathrm{mg} / \mathrm{cm}^{3}$ of the extract is not effective on such bacteria, and its possible that some bacteria can use defensive agencies against the extract molecules [18].

Finally, no inhibitory activity was detected using all types of the plant extracts against Serr. marcescens, Sal. typhimurium and Kleb. pneumoniae, this may be attributed to the fact that Gram-negative cell wall is a multilayer structure and quite complex, in addition to the presence of lipids and polysaccharides which can be defensive agencies [14], and the role of secreted exoenzyme in defending bacteria against plant extracts [19]. 
Table 2: Antibacterial activity of Hexane and Acetone extracts from $R$. crispus L. roots.

\begin{tabular}{|c|c|c|c|c|c|c|c|c|c|c|c|c|c|c|}
\hline \multirow{2}{*}{ Microorganisms } & \multicolumn{5}{|c|}{$\begin{array}{c}\text { Hexane extract } \\
\text { concentrations } \mathrm{mg} / \mathrm{cm}^{3}\end{array}$} & \multicolumn{5}{|c|}{$\begin{array}{c}\text { Acetone extract } \\
\text { concentrations } \mathrm{mg} / \mathrm{cm}^{3}\end{array}$} & \multicolumn{4}{|c|}{ Control } \\
\hline & 200 & 100 & 50 & 25 & 12.5 & 200 & 100 & 50 & 25 & 12.5 & $\mathbf{T E}$ & $\mathbf{A X}$ & $\mathbf{C N}$ & CL \\
\hline S. aureus & 12.2 & 11.5 & 8.2 & $\mathrm{R}$ & $\mathrm{R}$ & 17.3 & 13.3 & 12.1 & 9.3 & 8.2 & - & $\mathrm{R}$ & - & - \\
\hline Ps. aeruginosa & 21.3 & 19.2 & 10.5 & $\mathrm{R}$ & $\mathrm{R}$ & 19.6 & 16.1 & 15.2 & 12.4 & 10.3 & - & - & 19.1 & - \\
\hline Pr. vulgaris & $\mathrm{R}$ & $\mathrm{R}$ & $\mathrm{R}$ & $\mathrm{R}$ & $\mathrm{R}$ & 11.6 & 10.1 & 8.4 & $\mathrm{R}$ & $\mathrm{R}$ & $\mathrm{R}$ & - & - & - \\
\hline Ser. marcescens & $\mathrm{R}$ & $\mathrm{R}$ & $\mathrm{R}$ & $\mathrm{R}$ & $\mathrm{R}$ & $\mathrm{R}$ & $\mathrm{R}$ & $\mathrm{R}$ & $\mathrm{R}$ & $\mathrm{R}$ & - & - & 19.2 & - \\
\hline E. coli & $\mathrm{R}$ & $\mathrm{R}$ & $\mathrm{R}$ & $\mathrm{R}$ & $\mathrm{R}$ & 21.3 & 17.4 & 14.2 & 11.1 & $\mathrm{R}$ & - & - & 13.4 & - \\
\hline Kleb. pneumoniae & $\mathrm{R}$ & $\mathrm{R}$ & $\mathrm{R}$ & $\mathrm{R}$ & $\mathrm{R}$ & $\mathrm{R}$ & $\mathrm{R}$ & $\mathrm{R}$ & $\mathrm{R}$ & $\mathrm{R}$ & - & - & - & 16.2 \\
\hline
\end{tabular}

R: Resistant, - : Not used, TE: Tetracycline, AX: Amoxicillin, CN: Gentamycin, CL: Cefalixin 1 


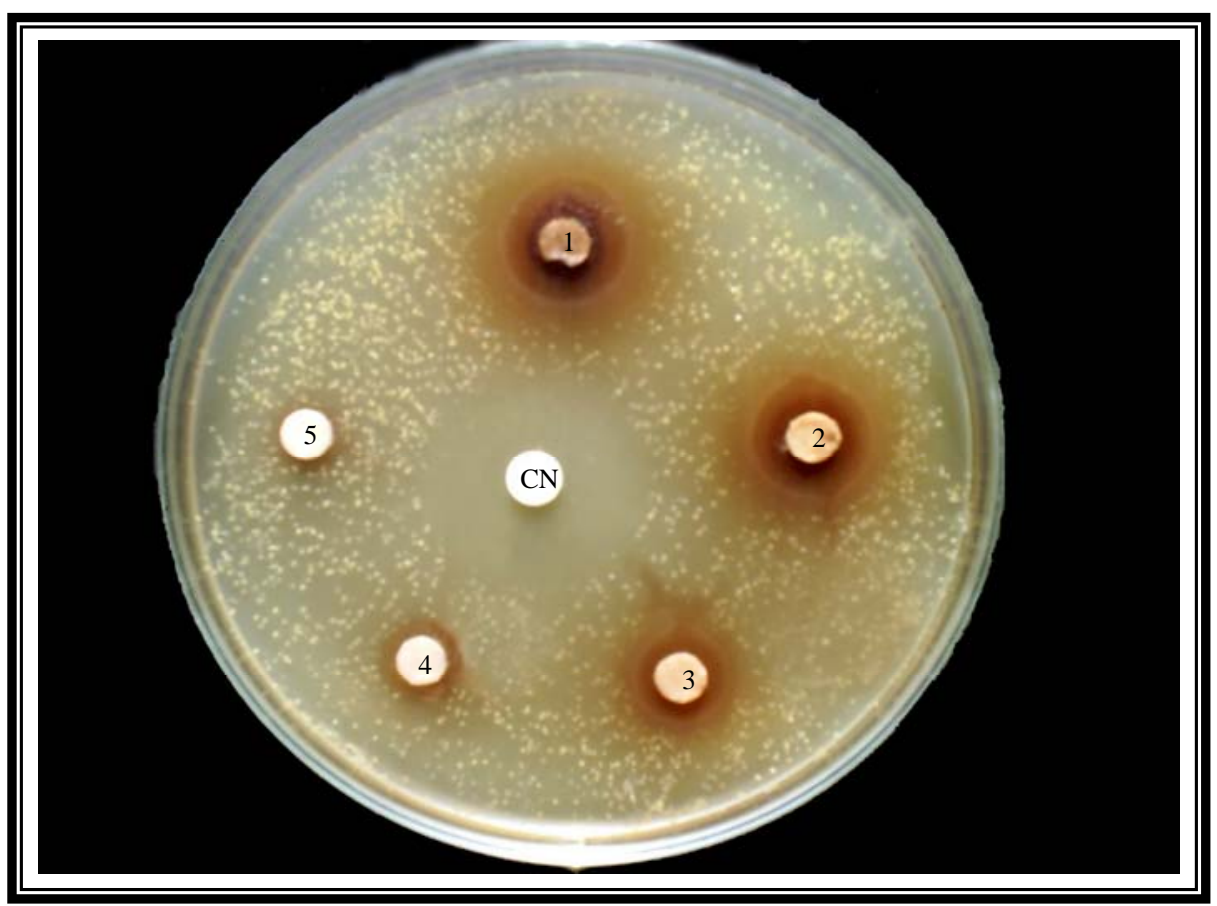

Figure 2(A):Effect of Acetone extract on $\boldsymbol{E}$.coli using different concentration , $1\left(200 \mathrm{mg} / \mathrm{cm}^{3}\right) 2\left(100 \mathrm{mg} / \mathrm{cm}^{3}\right) 3\left(50 \mathrm{mg} / \mathrm{cm}^{3}\right)$ $4\left(25 \mathrm{mg} / \mathrm{cm}^{3}\right) 5\left(12.5 \mathrm{mg} / \mathrm{cm}^{3}\right) \mathrm{CN}($ Gentamycin $)$.

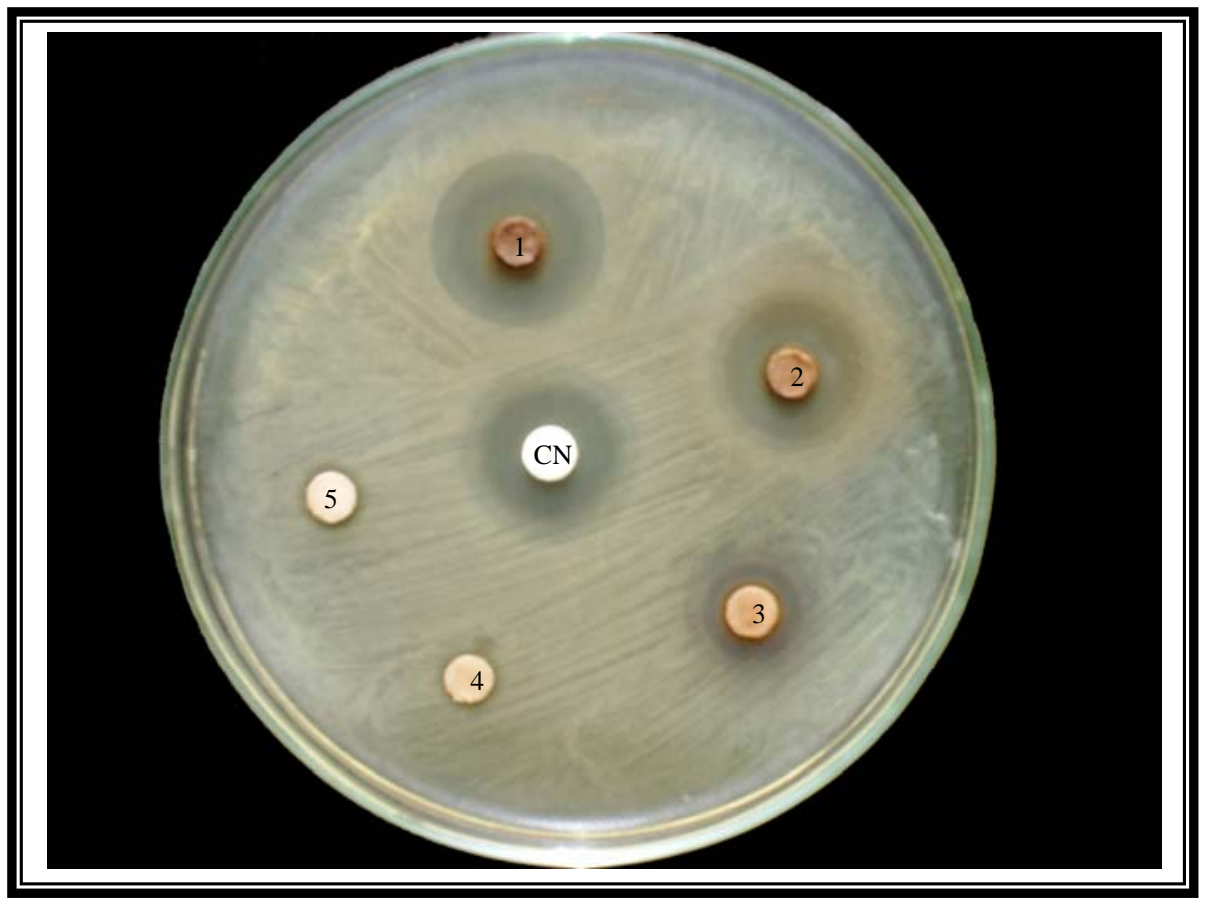

Figure 2(B):Effect of hexane extract on Ps .aeruginosa using different concentration, $1\left(200 \mathrm{mg} / \mathrm{cm}^{3}\right) 2\left(100 \mathrm{mg} / \mathrm{cm}^{3}\right)$ $3\left(50 \mathrm{mg} / \mathrm{cm}^{3}\right) 4\left(25 \mathrm{mg} / \mathrm{cm}^{3}\right) 5\left(12.5 \mathrm{mg} / \mathrm{cm}^{3}\right) \mathrm{CN}($ Gentamycin $)$. 


\section{References}

1. Sezik, E., Yesilada, E., Honda, G., Takaishi, Y., Takeda, Y., Tanaka, T., Journal of Ethnopharmacology, 75: 95-111 (2001).

2. Zaller, J., Weed Research, 44: 414-432 (2004).

3. Baskan, S., Ozdemir, A., Gunaydin, K., Erim, F., Talanta, In press (2006).

4. Yesilada, E., Sezik, E., Honda, G., Takaishi, Y., Takeda, Y., Tanaka, T., Journal of Ethnopharmacology, 64: 195-210 (1999).

5. Gunaydin, K., Topcu, G. and Ion, R., Natural Product Letters, 16: (1) 65-70 (2002).

6. Alzoreky, N. and Nakahara, K., International J. of Food Microbiology, 80: 223-230 (2003).

7. Desta, B., Journal of Ethnopharmacology, 39: 129-139 (1993).

8. Rios, J., Recio, M. and Villar, A., Journal of Ethnopharmacology, 21: 139- 152 (1987).

9. Grand, A., Wondergem, P., Verpoorte, R. and Pousset, J., Journal of Ethnopharmacology, 22: 25-31 (1988).

10. Dulgar, B. and Gonuz, A., Asian Journal of Plant Science, 3: (1) 104107 (2004).

11. Bauer, A., Kirbay, W., Sherris, J. and Turk, M., Am. J. Clin. Pathol., 45: 493-496 (1966).

12. Shale, T., Stirk, W. and Staden, J., Journal of Ethnopharmacology, 67: 347-354 (1999).

13. Haslam, E., J. Nat. Prod., 59: 205-215 (1996).

14. Ya, C., Gaffney, S., Lilley, T. and Haslam, E., Plenum Press, New York, N.Y. (1988).

15. Berger-Bächi, B., Int. J. Med. Microbiol., 292: 27-35 (2002). 
16. Essawi, T. and Srour, M., Journal of Ethnopharmacology, 70: 343349 (2000).

17. Ulukanli, Z., Ulukanli, S., Ozbay, H., Ilcim, A. and Tuzcu, M., Pharmaceutical Biology, 43: (4) 334-339 (2005).

18. Sagdic, O., Kuscu, A., Ozcan, M. and Ozcelik, S., Food Microbiology, 19: 473-480 (2002).

19. Kazmi, M., Malik, A., Hameed, S., Akhtar, N. and Noor Ali, S., Phytochemistry, 36: 761-763 (1994). 